\title{
有棘縫合糸断端の処理の工夫
}

高山赤十字病院産婦人科

加藤雄一郎、溝口冬馬、矢野竜一朗

\section{Management of the cut end of a barbed suture}

\author{
Yuichiro Kato, Toma Mizoguchi, Ryuichiro Yano
}

Department of Obstetrics and Gynecology, Japan Red Cross Takayama Hospital

\begin{abstract}
Barbed sutures are widely used to suture the myometrium in cases of cesarean delivery and myomectomy, as well as to suture the vaginal stump in hysterectomy. Although barbed sutures facilitate rapid and accurate tissue approximation, protrusion of the cut end of the suture into the abdominal cavity and subsequent entanglement in the intestinal tract or mesentery can cause bowel obstruction or volvulus. We report a case of strangulated ileus after laparoscopic myomectomy using barbed sutures. We ligated the cut end of the barbed suture using another suture and cut it as short as possible. The patient has shown no complications postoperatively. We report our novel suturing method, which could be useful clinically in such cases.
\end{abstract}

Key words: barbed suture; bowel obstruction; ligature with vicryl

\section{〈緒 言〉}

有棘綘合糸は、帝王切開や子宮筋腫摘出術にお ける子宮筋層縫合や、子宮摘出術における腟断端 の縫合に広く用いられている。縫合が容易で緩み にくいという利点がある一方、糸の断端が原因と なってイレウスを来たした報告が散見される ${ }^{1,2)}$ 。 糸の切断端が腹腔内に突出した場合に腸管や腸間 膜に癒着すると、イレウスを生じる原因となる。 当院でも腹腔鏡下子宮筋腫摘出術後の絞扼性イレ ウスを経験した。その後有棘縫合糸の切断端を別 の縫合糸と結杽し、更に有棘縫合糸をできるだけ 短く切るという対策を講じている。有棘縫合糸断 端が跳ねて腹腔内に突出しない様にする目的で始 めたが、有棘縫合糸の縫合末端付近がより締まる 効果も期待できると考えている。今回報告する縫 合を実施してからは同様の合併症は生じていな い。有用な縫合方法であると考えられたため報告
する。

論文作成においてはすべての患者の同意を得 た。

\section{〈合併症症例提示〉}

症例は42歳G1P1、子宮体部前壁筋腫30 mmに 対して腹腔鏡下子宮筋腫摘出術を行った。筋腫摘 出後の筋層は、STRATAFIX Spiral PDS Plus ${ }^{\circledR}$ (ジョンソン・エンド・ジョンソン株式会社）（以 下STRATAFIX Spiral）0号を使用し、筋層から 漿膜まで連続で縫合した。2 回返し縫いを行い、 子宮漿膜から糸の断端が突出しない様に切断した。 子宮表面にアドスプレー ${ }^{\circledR}$ 散布し手術を終了し た。図 1 に手術時の画像を示す。術後 4 日目に退 院した。術後 7 週間目に腹痛にてERを受診した。 血圧109/60 mmHg、心拍数52、体温 $37.7{ }^{\circ} \mathrm{C}$ であ った。受診時の所見を図 2 に示す。絞扼性イレウ スの診断で緊急手術を行ったところ、子宮体部前 


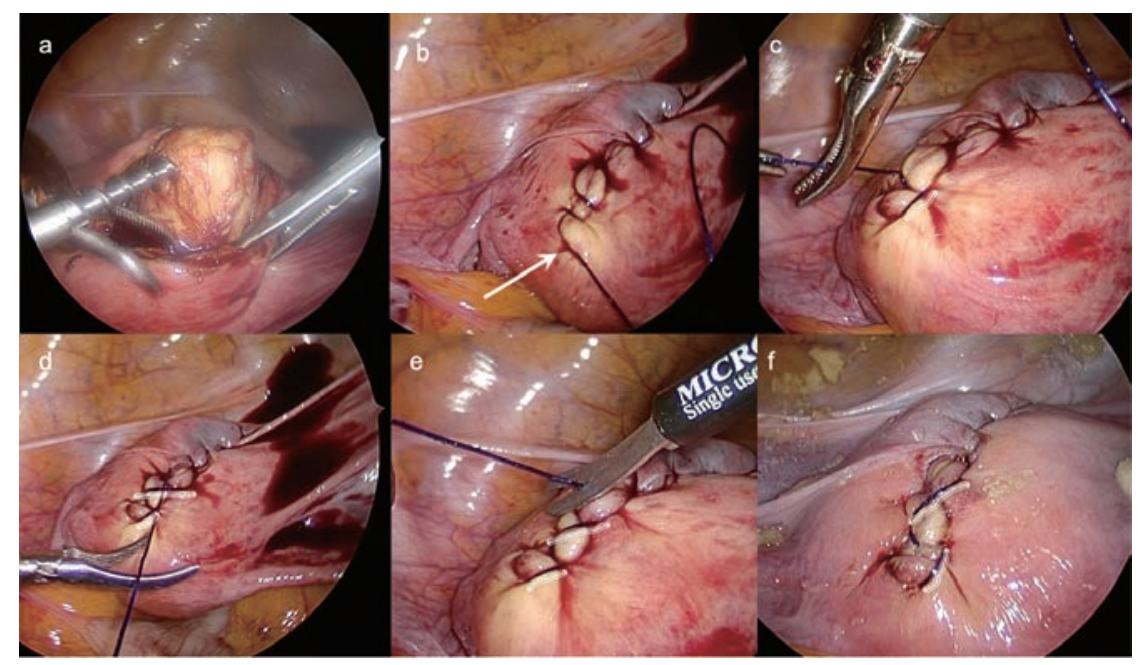

図 $1 a$ ：子宮筋腫を核出した。前壁筋層内筋腫であった。b：0-STRATAFIX spiralで筋層から漿膜 まで連続で縫合したところ。矢印で断端を示す。c：1回目の返し縫いを行ったところ。返し 縫いの糸を点線で示す。d: 2 回目の返し縫いを行ったところ。e : 漿膜面から突出しないよう に切断するところ。 $f$ : 手術終了時。系の突出、跳ねを認めない。

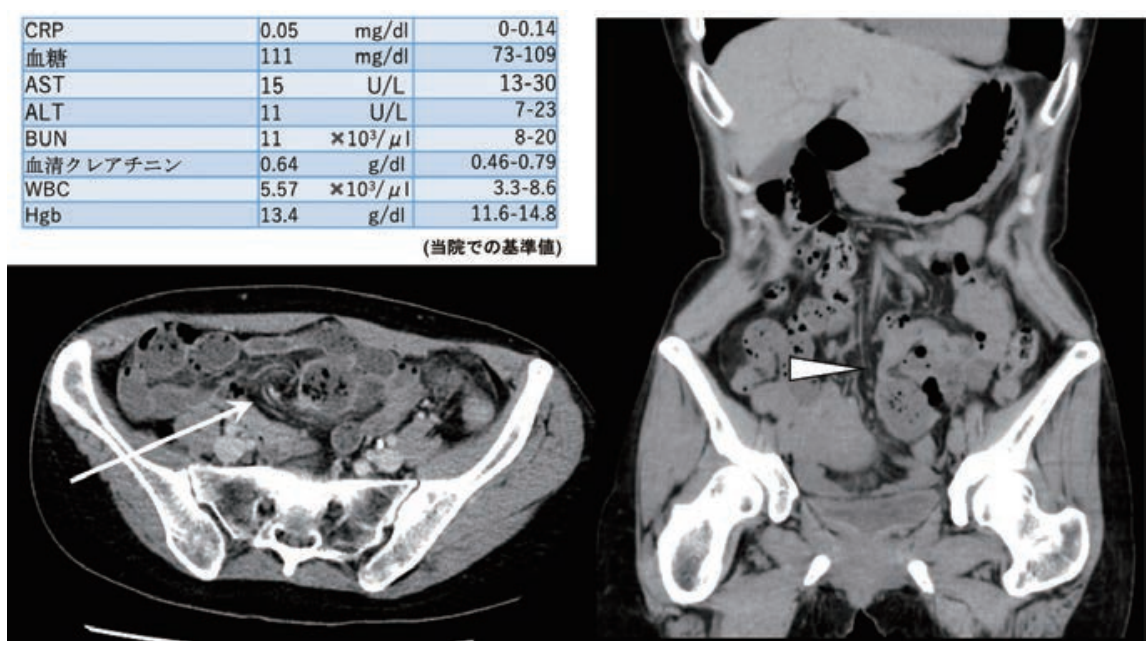

図2 ER受診時の血液検査、CT画像を示す。血液検査：明らかな炎症反応上昇を認めなかった。 $\mathrm{CT}$ ：子宮頭側の腸管膜に捻れを矢印で示す。小腸の閉塞起点を三角で示す。

壁より突出する縫合糸が小腸間膜に刺入、瘉着し ており、bandを形成していた（図 3 )。小腸壊死 を認めず、bandを形成していた糸を切除し手術 を終了した。術後 1 日目より離床と飲水を開始し、 2 日目より食事を開始した。術後 7 日目に退院し た。その後は腸閉塞の再発を認めていない。

\section{〈手技手順〉}

腹腔鏡下手術における有棘縫合糸と他の縫合糸 との結紮について述べる。図 4 に実際の症例での 手順を、図 5 にシェーマを示す。腹腔鏡下子宮筋 腫摘出術の場合、当院ではSTRATAFIX Spiralを 用いている。縫合する筋層が深い場合は 0 号を用 いて、浅い場合は $2-0$ を使用する。筋層を縫合
しそのまま漿膜縫合を行うが、糸が短くなった場 合は $2-0$ に変えて漿膜を縫合する。その際、筋 層縫合に使用した糸は、糸の断端が漿膜に突出し ないように切断する。漿膜面まで縫合し終わった ら、STRATAFIX Spiralを $1 \mathrm{~cm}$ 程度突出するよう に切断する。そして 3 - 0 vicryl ${ }^{\circledR}$ をSTRATAFIX Spiral断端付近の子宮漿膜に1針単結節縫合し、 その $3-0$ vicryl $^{\circledR}$ の一方の糸をlong tailとし、 STRATAFIX Spiral断端を short tailとして結禁 する。STRATAFIX Spiralの縫合末端部分はよ り締まり、Barbがあるためvicrylとの結節も緩み にくい。STRATAFI Spiralとvicrylは、ほどけな いように 3 回結紮している。結紮が終われば STRATAFI Spiralはできるだけ短く切断する。 


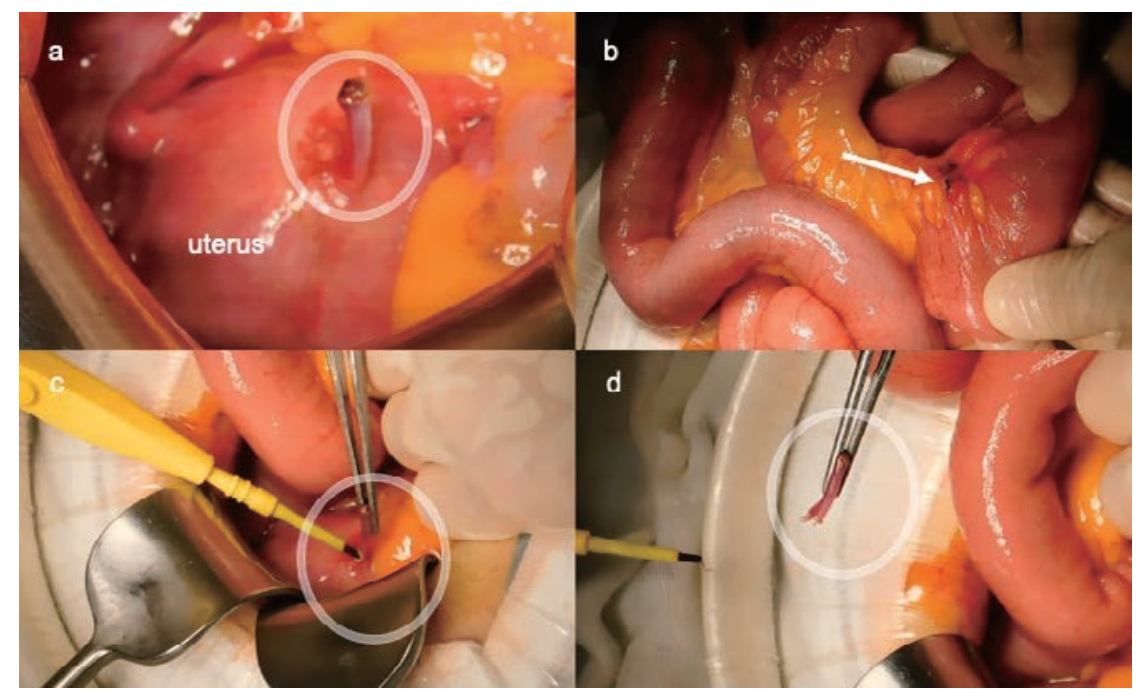

図3イレウスに対する手術時の所見を示す。子宮前壁より突出する0-STRATAFIX spiralを丸で囲 む。a : 小腸間膜側でO-STRATAFIX spiralを切断した後の子宮前壁。 $2 \mathrm{~cm}$ 程度縫合糸が突出し ていた。b：小腸間膜に刺入していた部位を矢印で示す。c：子宮から突出する0-STRATAFIX spiralを電気メスで切除した。d：切除された縫合糸。糸の周囲にフィブリン様物質の析出が見 られた。

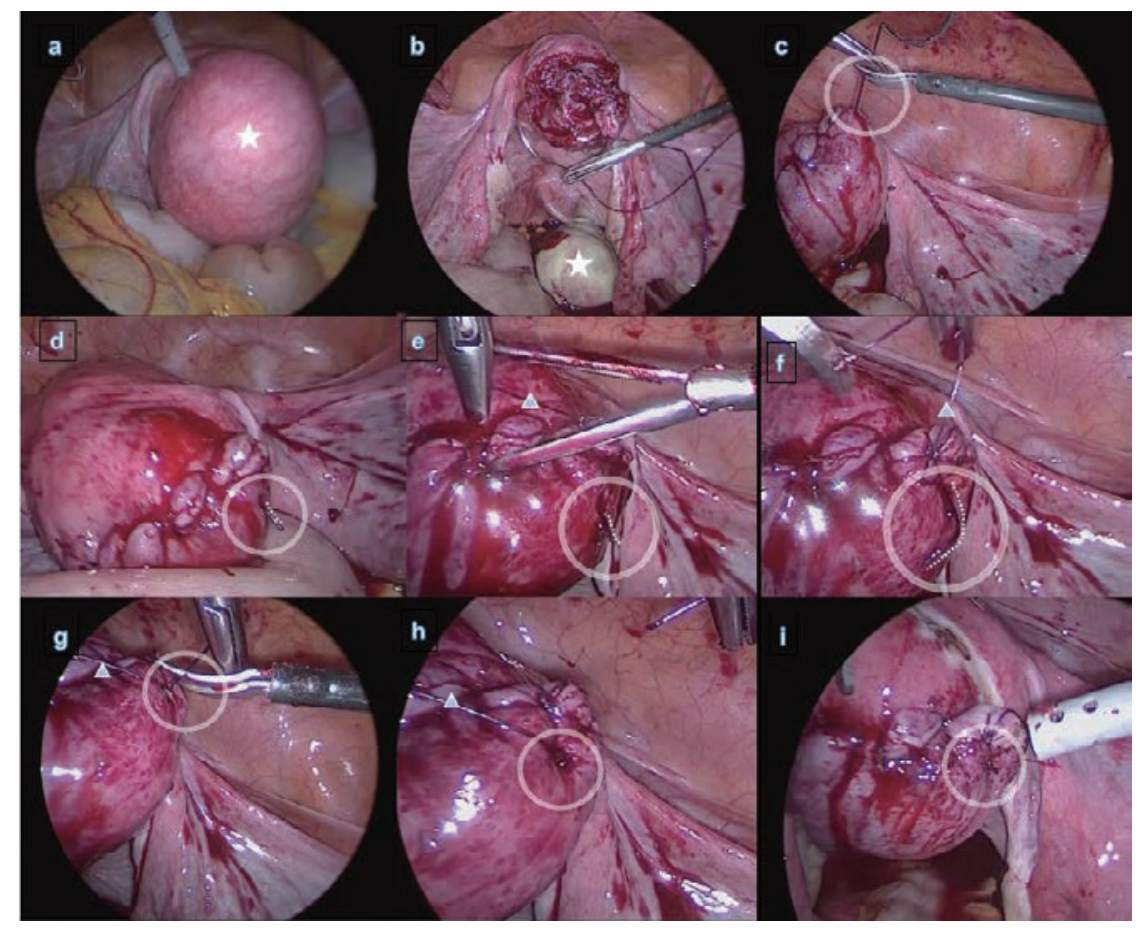

図4 腹腔鏡下子宮筋腫摘出術における縫合方法を示す。O-STRATAFIX spiralの断端を丸で囲む。 子宮筋腫をえで、3-0 vicrylをムで示す。

$\mathrm{a}$ ：後壁筋層内に50 mmの筋腫を認める。 $\mathrm{b}$ ：筋腫摘出後。c：0-STRATAFIX spiralで筋層から 漿膜まで連続縫合し切断する。d：切断後のSTRATAFIX spiralを破線で示す。約 $5 \mathrm{~mm}$ 程度子 宮漿膜から突出している。e : STRATAFIX spiral断端の近傍に $3-0$ vicrylを単結節縫合する。 $\mathrm{f}$ : vicrylをSTRATAFIX spiralと結禁したところ。STRATAFIX spiralの緩みがなくなり、締ま った分だけ漿膜面から突出する長さが延長している。g：vicrylを 3 回結紮し、STRATAFIX spiral なるべく短く切断する。 $\mathrm{h} 、 \mathrm{i}$ : 漿膜面からSTRATAFIX spiralの突出がほとんどない状 態となる。

漿膜面からはSTRATAFIX Spiralの突出はほと んどなく、突出している部位もvicrylと結禁され ているためbarbの露出も抑えられる。

\section{〈考察〉}

有棘縫合糸の有用性は、帝王切開や腹腔鏡下子 宮筋腫摘出術の筋層縫合において広く確認されて 


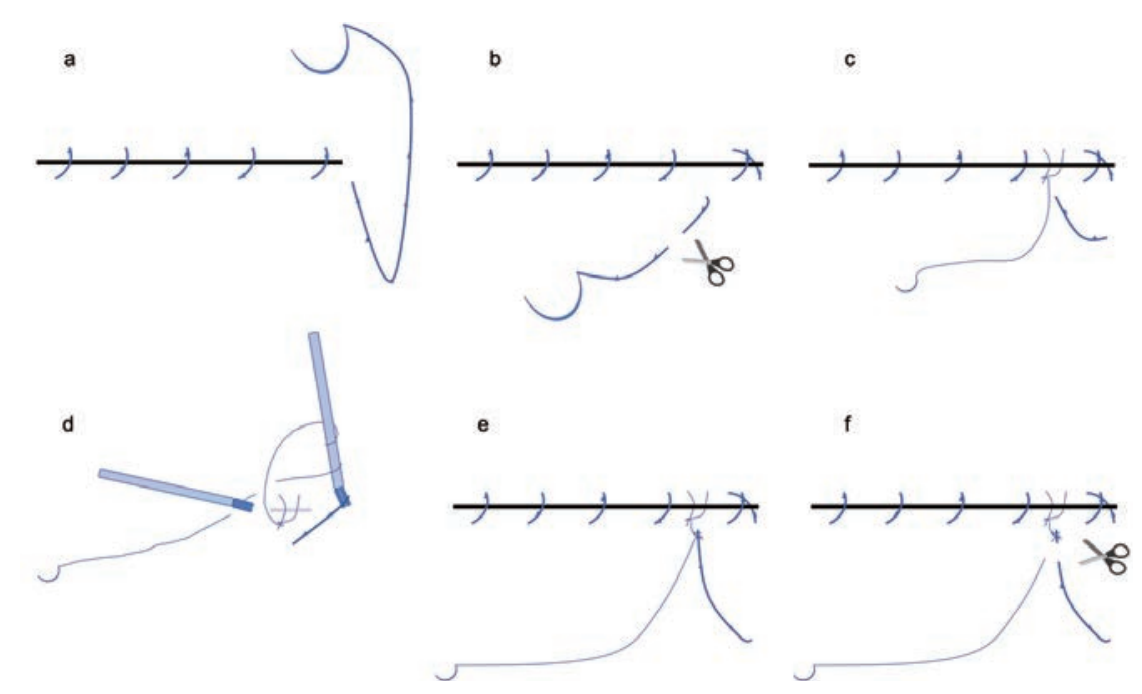

図 5 a : 子宮漿膜面断端までSTRATAFIX spiralで連続縫合したところ。b：返し縫いを行い、糸を 切断する。c：断端近傍に $3-0$ vicrylを単結節縫合する。d：縫合結紮した $3-0$ vicrylの一方 の糸とSTRATAFIX spiralの断端を 3 回縫合する。e : 縫合が終了したところ。f : STRATAFIX spiralの突出がないように切断する。

いる ${ }^{3-5)}$ が、腹腔内への突出を防ぐことが合併症 の予防に重要であると考えられる。STRATAFIX Spiralは、全ての有棘縫合糸と同様に全く緩まな いわけではない。他の有棘縫合糸と比べてbarb が小さいため、緩みやすい可能性がある。逆に barbが小さいために組織への侵襲は小さく、ま た腹腔内へ突出した時にも腸管等への癒着が生じ る可能性も低いと考えられる。当院での糸の選択 は、barbの大きさと組織への侵襲を勘案して STRATAFIX Spiralを選択している。有棘縫合 糸による消化管閉塞の頻度は不明であるが、 3 $\mathrm{mm}$ 程度の腹攻内への突出でもイレウスを生じた 報告もある ${ }^{6)}$ 。添付文書上の使用方法は、2 回程 度返し縫いを行ってから、糸の突出がないように 切断する。この時の注意点は、切断後に縫合糸が 全く緩まないというわけではないことである。な るべく突出を少なくするために短く切りたいが、 あまり短くきると緩みが生じた際には糸が抜けや すくなり、跳ねる可能性がある。 vicryl 結紮す ることで糸跳ねが予防できると考えた。当院でも 前述の症例のように返し縫いを行なっているにも 関わらず、有棘縫合糸による絞扼性イレウスが生 じた。イレウス手術時の所見では、長く跳ねた糸 が小腸間膜に刺入し、癒着していた。返し縫いし た糸断端が1針分抜けて跳ねたことが原因ではな いかと推察された。縫合糸断端が腹腔内へ突出す る原因として、返し縫いで組織への刺入が浅いと、 組織と引っかかるbarbが少なくなり緩みやすく なる。また返し縫いのpitchが大きいと、糸が跳
ねた場合に突出する長さが長くなる可能性があ る。今回の症例のビデオを見返してみると、返し 縫いのpitchは適当であったが、組織への刺入が 浅かった可能性があり、そのために糸が緩み、跳 ねが生じた可能性があると考えられた。

今回報告した手術手技の利点は、STRATAFIX Spiralを短く切っても抜けや跳ねが抑えられる可 能性が高くなること、STRATAFIX Spiralがより 締まることである。欠点としては、 $3-0$ vicryl を縫合結紮する手間が増えることであるが、手技 自体は容易であり、煩雑なものではない。また vicrylの方が抗張力持続期間が短く、吸収が早い ため、1 ケ月後にはSTRATAFIX Spiralだけ残 っている可能性がある。ただし、vicrylの吸収が 進むのと同時にSTRATAFIX Spiralと子宮筋層 との癒着も進み、STRATAFIX Spiralの緩み、 跳ね、突出が予防できるのではないかと考察して いる。STRATAFIX Spiral と縫合する糸に 3 0 vicrylを選択した理由は、柔らかい糸の方が STRATAFIX Spiral を傷めないと考えたからで ある。比較はしていないが、PDSなど硬い糸との 結紮ではSTRATAFIX Spiralが折れたりして強 度が落ちる可能性があると考える。今回報告する 断端処理を行う様になってから、子宮筋腫核出術 に10例実施しているが、縫合糸による術後合併症 は認めていない。有棘縫合糸によるイレウスはま れな合併症と考えられるが、今後の症例の蓄積を 待って本縫合方法の有効性を確認したい。

有棘縫合糸断端による合併症の予防の取り組み 
は、腹膜外への“隠し縫い”や7)、腹腔内に突出し ない様に腹膜や漿膜で覆ったり、漿膜縫合には有 棘縫合糸を使わないなどの報告がある。気腹圧を $4 \mathrm{cmH}_{2} \mathrm{O}$ 程度に下げて緩みを確認したり、でき るだけ突出しない様に短く切る等の対策が取られ ている ${ }^{1,2)}$ 。癒着防止材は効果がそしい可能性があ $る^{8)}$ 。当施設内の議論においても、漿膜面はvicryl で縫合するという意見も出たが、STRATAFIX Spiralで漿膜面まで縫合した方が漿膜の寄りも良 いと判断した。施設によっては、漿膜面に有棘縫 合系を使用しないという対応も考えられる。

子宮筋腫摘出術の子宮漿膜縫合に有棘縫合糸を 使用するのであれば、今回報告した断端処理を行 うことを推奨したい。

\section{〈結 論〉}

有棘縫合糸断端の処理について、他の縫合糸と 結紮する工夫を行った。返し縫いを行うだけに比 べ一手間増える欠点はあるが、手技は単純で有棘 縫合糸の締まりが良くなり、糸抜けや跳ねの可能 性が低くなると考えられ、有用であると考える。 全ての著者に利益相反はない。

\section{〈文 献〉}

1 ）川村洋介、他: TLH術後に有棘縫合糸により絞抳性イ レウスを発症した1例、日産婦内視鏡学会誌、2017; 33: 182-185.

2 ）小林壽範、他: TAPP術後に吸収性有棘連続縫合糸に より小腸イレゥスを呈した1例、日鏡外会誌、2016; 21: $283-287$

3 ）加藤雄一郎、他: 帝王切開術の子宮筇層縫合に扔ける 有棘綘合糸の使用経験、日周産期・新生児会誌、 2020; 56: 213-217.

4 ) Barbara Gardella, et al.: What is the Role of Barbed Suture in Laparoscopic Myomectom? A MetaAnalysys and Pregnacy Outcome Evaluation. Gynecol Obstet Invest 2018; 83: 521-532.

5 ）百枝幹雄: 子宮筋腫 手術療法 2013; 55、株式会社 診断と治療社.

6 ）黑河内喬範、他: 腹㛊鏡下ヘルニア修復術の腹膜閉鎖 に用いたBarbed Suture（有棘縫合系）が術後癒着性 イレウスをきたした1例、日鏡外会誌、2015; 20: 187191

7 ）亀井文、他:「隠し縫い」を用いた腹膜縫合 - 有棘縫 合糸に伴う合併症予防をめざして、日鏡外会誌、 2017; 22: 845-850.

8) Kindinger L, Setchell T, Miskry T: Bowel obstruction due to entanglement with unidirectional barbed suture following laparoscopic myomectomy. 